\title{
Hjelp til pårørende
}

\section{- Jeg er utslitt. Nå er jeg snart}

81 år, og ennå får jeg ikke fred. sa damen som ringte meg en sen kveldstime. I to timer fortalte hun om hvordan hennes velutdannede sønn stjal penger, løy og bedro henne, slik han hadde gjort helt siden han ble hektet på alkohol som 20-åring. Nå er han 57 år.

Da jeg spurte om hun ikke fikk hjelp, returnerte hun spørsmålet med: - Fra hvem? Jeg fortalte at jeg ikke riktig visste hva jeg kunne bidra med, hvorpå hun svarte: - Du har hjulpet meg. Jeg trengte et $\varnothing$ re som forstår.

Spørsmålet hennes illustrerer saken: Hvem vet hvem som skal hjelpe, og hvem skal finne hvem som trenger hjelp?

Sønnen hadde aldri vært innom helsevesenet på grunn av rusproblemet, heller ikke vært i konflikt med rettsvesenet. Kun nære bekjente, kolleger og arbeidsgivere som hadde gitt ham sparken på grunn av fyll, hadde anelse om at han slet med alkohol utenom barna, ekskoner og moren som tok belastningen. Dette er de mest typiske pårørende til rusavhengige. De som lever bak fine fasadegardiner. Det er disse det er flest av.

De kommer til legen med somatiske helseplager: Kvinner med skjelett- og nakkeplager, tarmlidelser og andre symptomer. Barn får AD/HD-diagnoser fordi skolehelsetjenesten, lærere og foreldre ikke aksepterer eller forstår barnets atferd på annen måte. Menn sliter med depresjoner, potensproblemer og følelsen av utilstrekkelighet.

Legen måler blodtrykk, tar nødvendige blodprøver og finner sjelden ut noen årsak til plagene, fordi legen ikke stiller det rette spørsmålet: - Er det noen i familien din som sliter med rus?

Tidligere fastlege for flere hundre tunge rusavhengige gjennom flere år, Dagfinn Haarr, nå kommuneoverlege i Kristiansand, uttalte i et foredrag at fastlegers største tabu overfor pasientene er å stille spørsmål om sex og rus.

I så fall er det hovedgrunnen til at vi ikke når frem til det store flertallet av pårørende til rusavhengige. De som er pårørende til rusavhengige som har vært eller er innlagt ved institusjon, er det enkelt å finne frem til. Mange av disse deltar i familieuken, en ukes undervisning sammen med rusavhengige. De får kunnskap og veiledning. $\mathrm{Og}$ de får det bedre fordi de blir behandlet på samme måte som det rusavhengige blir. De får også en diagnose å forholde seg til: medavhengighet.

De er like avhengige av den rusavhengige som den rusavhengige er av rusen. Selv husker jeg hvor stille vi listet oss de helgene min far hadde noen hvite dager. Vi tenkte at bare vi ikke støyer eller irriterer, så slipper han å begynne å drikke igjen. For drakk han, så kjeftet mamma, og dermed var krangelen i gang.

Jeg liker medavhengighetsdiagnosen. Ingen trenger behandling for å være pårørende til noen. Vi kan bære preg av å være nær noen, men det blir for diffust. Derimot: Medavhengig til alkoholikeren, til den narkomane, det gir en knagg å henge de reelle symptomene på. Og så spesialisert som rusfeltet er blitt siden reformen i 2004, så trenger vi konkrete knagger. Ikke minst trenger fastlegene dette.

- Dette har du mer greie på enn meg. sier min fastlege når jeg tar opp saker rundt denne problematikken med ham. Og han er blant de mest «utdannede» fastlegene, fordi han har vært med på hele min reise i 30 år. Jeg var en pasient som feilte mye da jeg kom til han: Høyt blodtrykk, allergier, depresjoner osv. Etter hvert erkjente jeg min alkoholisme. Det er nå 26 år siden, og jeg har vært tørr siden.

Med åpenhet rundt min egen erfaring, og ikke minst ut fra plattformen Stiftelsen Klar og Gatemagasinet Klar som jeg både gründet og driver, har jeg oppnådd tillit hos mennesker som sliter med rusrelaterte problemer. Både avhengige og pårørende. Hver uke får jeg mange telefoner og annen kontakt fra mennesker som trenger veiledning, noen ganger bare et «øre som forstår». Dette er et tegn på hvor stort behovet er.

Rettighetene til hjelp for pårørende er gode, men lite tilgjengelig - fordi fastlegene mangler kunnskap. Når pårørende blir henvist til behandling fra fastlege, blir det ofte til psykiatrien. Dermed mister de den innsikten i sin medavhengighet som de ville ha fått om de ble behandlet av fagfolk fra rusfeltet. Mitt håp på vegne av pårørende er at direktoratet i sine veiledere endrer, eller tilføyer, medavhengighet som tilstandsbegrep.

En annen bønn: At Legeforeningen som fagorganisasjon pålegger fastleger å kurses i hvilke symptomer som er typisk for medavhengighet. Fastlegene bør også i større grad bruke tilgjengelige verktøy for å se om pasientens symptomer kan skyldes storkonsum av alkohol, eksempelvis CDT-verktøyet (Carbohydrate deficient transferrin).

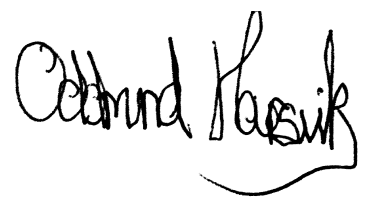

